\title{
Experimental murine mycobacteriosis: evaluation of the functional activity of alveolar macrophages in thalidomide-treated mice
}

M.S.P. Arruda ${ }^{1}$ V.B. Richini ${ }^{1}$, S.M.A. Oliveira ${ }^{1}$ and F.R. Vilani-M oreno ${ }^{2}$

\author{
1Departamento de Ciências Biológicas, Faculdade de Ciências, \\ Universidade Estadual Paulista, Bauru, SP, Brasil \\ ${ }^{2}$ Equipe Técnica de Imunologia, Instituto Lauro de Souza Lima, \\ Bauru, SP, Brasil
}

\section{Correspondence \\ M.S.P. Arruda \\ Departamento de Ciências Biológicas \\ Faculdade de Ciências, UNESP \\ Av. Eng. Luiz Edmundo Coube, s/n \\ 17033-360 Bauru, SP \\ Brasil \\ Fax: + 55-14-3103-6070 \\ E-mail: sueli@fc.unesp.br}

Publication supported by FAPESP.

Received July 3, 2003

Accepted January 16, 2004

\section{Abstract}

Thalidomide is a selective inhibitor of tumor necrosis factor- $\alpha$ (TNF$\alpha$ ), a cytokine involved in mycobacterial death mechanisms. We investigated the role of this drug in the functional activity of alveolar macrophages in the presence of infection induced by intranasal inoculation of Mycobacterium avium in thalidomide-treated and untreated adult Swiss mice. Sixty animals were inoculated with $5 \times 10^{6} \mathrm{M}$. avium by the respiratory route. Thirty animals received daily thalidomide (30 $\mathrm{mg} / \mathrm{kg}$ mouse) and 30 received water by gavage up to sacrifice. Ten non-inoculated mice were used as a control group. Lots of animals from each group were evaluated until 6 weeks after inoculation. Infection resulted in an increased total number of inflammatory cells as well as increased activity of pulmonary macrophages. Histologically, intranasal inoculation of bacilli resulted in small mononuclear infiltrates located at the periphery of the organ. Culture of lung fragments revealed the presence of bacilli only at the beginning and at the end of the experimental period. Thalidomide administration did not affect the microbiological or histological features of the infection. Thalidomide-treated and untreated animals showed the same amount of $M$. avium colonies 3 weeks after infection. Although it did not affect bacillary clearance, thalidomide administration resulted in a decreased percent of spread cells and release of hydrogen peroxide, suggesting that factors other than TNF- $\alpha$ play a role in the killing of mycobacteria by alveolar macrophages. Thalidomide administration also reduced the number of spread cells among resident macrophages, suggesting a direct effect of the drug on this phenomenon.

\section{Introduction}

Infection by opportunistic mycobacteria, especially of the Mycobacterium avium complex, is a world health problem and is consid-
Key words

- Mycobacterium avium

- Alveolar macrophages

- Thalidomide

- Experimental infection ered to be the most common bacterial infection among immunosuppressed patients $(1,2)$.

Macrophages are the main host cells for these microorganisms. If macrophages present efficient microbicidal activity, the infec- 
tion is not established; however, if macrophages allow the bacilli to multiply, the infection is established and dissemination may occur (3). These bacteria may use several strategies to escape intracellular death. These include inhibition of the production and release of toxic metabolites, and the reduction of protein kinase $\mathrm{C}(\mathrm{PKC})$ production and/or phagolysosome formation (4-6), thus favoring their own survival inside the phagocytes. Therefore, activation of the bactericidal mechanisms of the cells is essential for the control of infection (7).

Among the factors studied, particularly important is tumor necrosis factor- $\alpha$ (TNF$\alpha$ ) which is mainly synthesized by macrophages. The local secretion of this cytokine is a double-edged sword, contributing either to protective immunity or to the immunopathology of disease. For example, increased TNF levels have been linked to the reversal reaction in leprosy and to cachexia in tuberculosis patients. On the other hand, TNF- $\alpha$ is critical for protection in murine mycobacteriosis (8). In addition to its other activities, TNF- $\alpha$ increases the adherence of neutrophils and monocytes to the endothelium, promotes inflammatory cell migration, and triggers local production of other pro-inflammatory cytokines $(9,10)$. Moreover, TNF- $\alpha$ induces the mycobactericidal and mycobacteriostatic activities of macrophages against intracellular microorganisms such as M. avium (11-13).

Since most of the studies conducted thus far on the mononuclear phagocytic system/ TNF- $\alpha /$ mycobacterial relationship have used peritoneal, spleen or bone marrow macrophages (14), and since alveolar macrophages show a different behavior concerning ingestion and facilitation of mycobacterial multiplication (15), we investigated the functional status of alveolar macrophages in the presence of infection induced by intranasal inoculation of M. avium in thalidomide-treated and untreated mice.

Thalidomide $(\alpha-\mathrm{N}$-phthalimidoglutara- mide) is a glutamic acid synthetic derivative with a well-known teratogenic effect. The inhibition of TNF- $\alpha$ production by thalidomide was demonstrated almost 40 years after its initial use as a medicinal drug (16). One of the activities of this cytokine is as a mediator of the mechanisms of mycobacterial cell death (3).

\section{Material and Methods}

\section{Animals}

Sixty 2-month-old male Swiss mice from the Animal House of Universidade Estadual Paulista, Botucatu Campus, were inoculated with $5 \times 10^{6} \mathrm{M}$. avium bacilli by the intranasal route. They were housed in groups of 3 to 5 animals and were provided with food and water ad libitum. Animals were divided into two groups: group $\mathrm{A}$, consisting of 30 mice which received $30 \mathrm{mg} / \mathrm{kg}$ body weight daily of thalidomide in sterile water by gavage, and group B, consisting of 30 mice which received daily the same amount of sterile water by gavage. The dose of thalidomide used was based on the results obtained by Sinhorini et al. (17) with mice. According to these investigators, the administration of thalidomide at this dose results in an effective reduction in serum TNF- $\alpha$ levels. Ten noninoculated mice, 5 of them treated with thalidomide and 5 left untreated, were also used as a control group and were submitted to a protocol identical to that for inoculated animals.

Lots of 5 animals from each group were sacrificed by ether inhalation at $6,24,72 \mathrm{~h}$ and at 1,3 and 6 weeks post-inoculation. After death, the lungs of the animals were collected and submitted to bronchoalveolar lavage.

\section{Bronchoalveolar lavage}

The bronchoalveolar lavage (BAL) was obtained by instillation and aspiration of 1 
$\mathrm{ml}$ of sterile saline solution (SSS) from the lungs, repeated 6 to 7 times. The suspension was centrifuged at $200 \mathrm{~g}$ for $10 \mathrm{~min}$ and the cell pellet resuspended in $1 \mathrm{ml} \mathrm{SSS}$. Samples of this material were submitted to the spreading and hydrogen peroxide $\left(\mathrm{H}_{2} \mathrm{O}_{2}\right)$ release procedures, to the determination of total number of cells and to examination for mycobacteria.

\section{Examination for mycobacteria in the BAL}

Samples of the cell pellet were cultured in Lowenstein-Jensen medium at $36-37^{\circ} \mathrm{C}$ for 4 to 8 weeks. The presence of colonies was estimated using a scale of zero to 3 crosses (+): $0=$ absent; $1=$ discrete; $2=$ moderate; $3=$ intense, and the presence of alcohol acid-resistant bacilli (BAAR) was determined by Ziehl-Neelsen staining (18).

\section{Determination of total number of cells in the BAL}

Ten microliters of a $0.5 \%$ crystal violet solution in $30 \%$ glacial acetic acid was added to $90 \mu \mathrm{l}$ of the BAL cell suspension. Counting was done in a Neubauer chamber and the results are reported as absolute numbers of cells.

\section{Evaluation of macrophage activity}

Spreading technique. According to the method of Rabinovitch et al. (19), after adherence to the glass surface, the cells of the BAL were incubated in 199 culture medium (Sigma, St. Louis, MO, USA) at $37^{\circ} \mathrm{C}$ for 60 min. Adherent cells were then fixed in $2.5 \%$ glutaraldehyde, stained with hematoxylineosin and examined under a light microscope. The percent of spread macrophages was determined in 100 cells.

$\mathrm{H}_{2} \mathrm{O}_{2}$ release. BAL cell suspensions were adjusted to $1 \times 10^{6}$ cells $/ \mathrm{ml}$ in phenol red solution containing peroxidase, transferred to a tissue culture plate and incubated in the presence or absence of $0.1 \mathrm{mg} / \mathrm{ml}$ phorbol myristate acetate (PMA; Sigma), according to the technique described by Russo et al. (20). The reaction was stopped by the addition of $1 \mathrm{~N} \mathrm{NaOH}(10 \mu \mathrm{l})$ and absorbance was measured with an ELISA microreader, using a $620-\mathrm{nm}$ filter, against a phenol red and $1 \mathrm{~N} \mathrm{NaOH}$ blank.

\section{Lung evaluation}

Lung fragments were decontaminated by the Petroffs method, cultured and maintained in Lowenstein-Jensen medium at $36-37^{\circ} \mathrm{C}$ for 4 to 8 weeks. The presence of colonies was estimated using a scale of 0 to 3 crosses $(+): 0=$ absent $; 1=$ discrete $; 2=$ moderate; 3 $=$ intense, and the presence of BAAR was determined by Ziehl-Neelsen staining (18). Lung fragments were also submitted to routine paraffin embedding and hematoxylineosin and Faraco-Fite staining $(21,22)$.

\section{Statistical analysis}

Data were analyzed statistically by nonparametric two-factor analysis of variance complemented with the respective multiple comparison tests (23).

\section{Results}

All the animals submitted to experimentation survived, and none of them showed clinical changes suggestive of infection.

\section{Histological evaluation}

Since thalidomide administration did not affect the histological picture of infected animals, the results were pooled. During early infection $(6,24$ and $72 \mathrm{~h}$ ), the pulmonary tissue showed small infiltrates predominantly consisting of mononuclear cells and mostly located on the edge of the organ. At day 7 no tissue changes were observed and after this period the organs showed a picture 
similar to that observed at the beginning of the experiment. During both periods, the infiltrate did not occupy more than $25 \%$ of the section.

\section{Search for mycobacteria in the pulmonary tract}

The results obtained from samples of

Table 1. Distribution of bacilli present in the bronchoalveolar lavage (BAL) and lung culture of thalidomide-treated (group $A$ ) and untreated Swiss mice (group B).

\begin{tabular}{lcccccc}
\hline \multirow{2}{*}{ Time of sacrifice } & \multicolumn{2}{c}{ Group A } & & \multicolumn{2}{c}{ Group B } \\
\cline { 2 - 3 } \cline { 6 - 7 } & BAL & Lung & & BAL & Lung \\
\hline $6 \mathrm{~h}$ & +++ & ++ & & ++ & + \\
$24 \mathrm{~h}$ & + & - & & - & - \\
$72 \mathrm{~h}$ & - & - & & - & - \\
1 week & - & - & & - & - \\
3 weeks & + & - & & - & - \\
6 weeks & ++ & ++ & & ++ & ++
\end{tabular}

- = negative; $+=$ discrete; $++=$ moderate $+++=$ intense.

Figure 1. Number of cells present in the bronchoalveolar lavage of Swiss mice infected with Mycobacterium avium and treated with thalidomide (black columns) or not (stippled columns). Values are reported as median number of cells.

Figure 2. Evaluation of the functional status of macrophages present in the bronchoalveolar lavage of thalidomide-treated (filled columns) and untreated (open columns) mice by the cell spreading technique. Data are reported as medians of percent. $+P<0.05$ compared to the untreated group (Kruskal-Wallis test). $* \mathrm{P}<0.05$ compared to the untreated infected group (Kruskal-Wallis test).
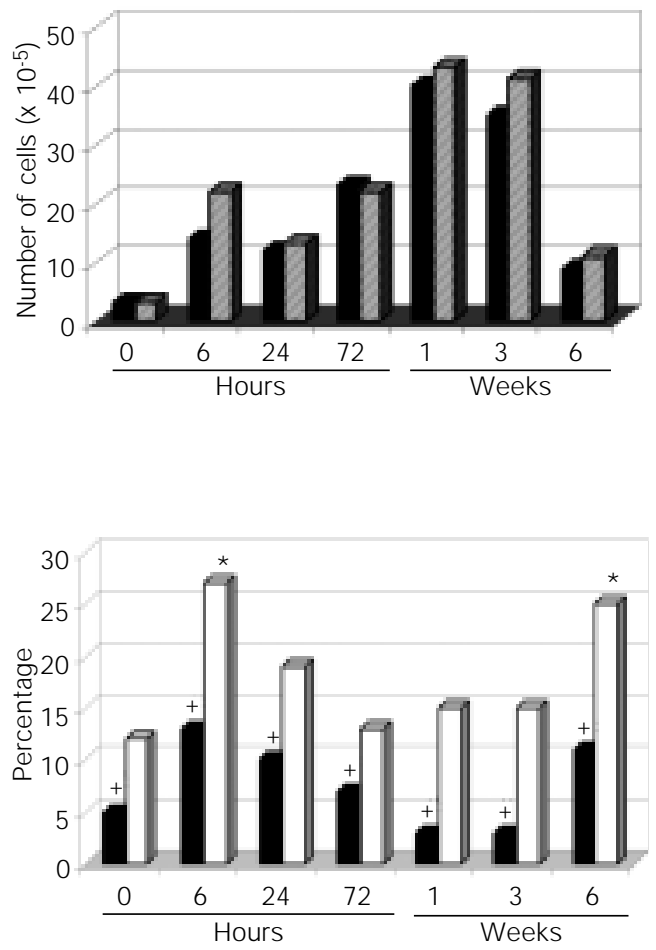

BAL and pulmonary fragment cultures are summarized in Table 1. Regardless of thalidomide administration, BAAR colonies were observed only at the beginning and at the end of the experiment.

\section{Total BAL cell counts}

The number of cells present in the BAL of $M$. avium-infected Swiss mice, treated or not with thalidomide, is presented in Figure 1. In non-infected mice submitted to a similar procedure (time zero), $3 \times 10^{5}$ cells $/ \mathrm{ml}$ were detected in the BAL regardless of thalidomide treatment. The afflux of cells to the pulmonary environment was significantly higher in infected animals than in healthy mice at all time points studied. Treatment with thalidomide did not significantly affect the number of cells recovered from the BAL. Moreover, in both groups studied, the evolution of infection resulted in a significant increase in the number of cells soon after $6 \mathrm{~h}$, with a peak occurring at the first and third weeks, followed by a decrease by the sixth week $(\mathrm{P}<0.05)$.

\section{Evaluation of macrophage activity}

Cell spreading. The percentage of spread macrophages present in the BAL of animals from both groups is summarized in Figure 2. In untreated animals the infection resulted in a significant increase in this parameter at the beginning $(6 \mathrm{~h})$ and at the end of the experiment (6th week). Thalidomide treatment induced a significant inhibition of alveolar macrophage spreading throughout the experiment, and also in the absence of infection (control group).

Determination of $\mathrm{H}_{2} \mathrm{O}_{2}$ release. The $\mathrm{H}_{2} \mathrm{O}_{2}$ release by BAL macrophages of Swiss mice is illustrated in Figure 3. In untreated animals the infection resulted in a significant increase in $\mathrm{H}_{2} \mathrm{O}_{2}$ release at the beginning and at the end of the experiment. It was also noted that thalidomide alone did not affect 
this parameter because in non-infected animals (time zero) there was no significant difference in spontaneous or induced release of this metabolite between thalidomidetreated and untreated animals. During infection, however, treatment significantly decreased spontaneous or PMA-induced $\mathrm{H}_{2} \mathrm{O}_{2}$ release.

\section{Discussion}

The data obtained in the present study demonstrate that inoculation of Swiss mice with $M$. avium by the intranasal route results in an increased afflux of cells to the pulmonary tract, an increased percentage of macrophage spreading, and increased levels of $\mathrm{H}_{2} \mathrm{O}_{2}$ released by macrophages present in the BAL, particularly at the beginning and at the end of the experiment, matching the detection of alcohol-acid resistant bacilli in the pulmonary tract.

The increased total number of inflammatory cells recovered from the BAL of experimentally infected mice is consistent with the results obtained by other investigators in different experimental studies $(3,24,25)$ and may be attributed either to the presence of mycobacterial lipoarabinomannan or to macrophage- and lymphocyte-derived mediators present in the focus of infection (26). In the present study, this result was obtained for both thalidomide-treated and untreated animals. In non-infected animals, thalidomide administration also did not affect the number of cells recovered from the BAL.

Thus, even though other investigators have reported the ability of this drug to inhibit leukocyte chemotaxis (27), our results demonstrate that in the present model thalidomide did not show a direct chemotactic effect on the afflux of cells to the pulmonary environment. The effect of thalidomide may be dose dependent in this process since Carneiro-Filho et al. (27), using a drug concentration of $45 \mathrm{mg} / \mathrm{kg}$ body weight, observed this phenomenon. The results ob- tained with IL-8, a potent chemotactic factor which appears to be dose dependently inhibited by thalidomide, support this premise (28).

On the other hand, in the present study, thalidomide administration at the dose used resulted in a reduction of the percent of macrophage spreading and of the levels of $\mathrm{H}_{2} \mathrm{O}_{2}$ released by alveolar macrophages of mice infected with the mycobacteria.

The spreading test is based on the ability of macrophages, when activated, to adhere to glass and to spread. Bilyk et al. (29), evaluating the spreading ability of alveolar macrophages in mice infected with the influenza virus, obtained a 10 to $14 \%$ rate of macrophage spreading, while in healthy mice the percentage was 3\%. Vilani-Moreno et al. (25), in similar studies, obtained an $8 \%$ rate for healthy animals and a 16 to $29 \%$ rate for $P$. brasiliensis-infected animals.

In the present study, non-infected mice not treated with thalidomide showed a $12 \%$ rate of macrophage spreading. In infected animals, this percentage was significantly increased, particularly when viable mycobacteria were detected in the pulmonary environment, suggesting that bacillary multiplication may act as a stimulus for macrophage activation and consequently for cell spreading. Thalidomide significantly inhibited macrophage spreading and this inhibitory effect was also observed in the absence of infection, suggesting a direct effect of the drug on macrophage spreading.

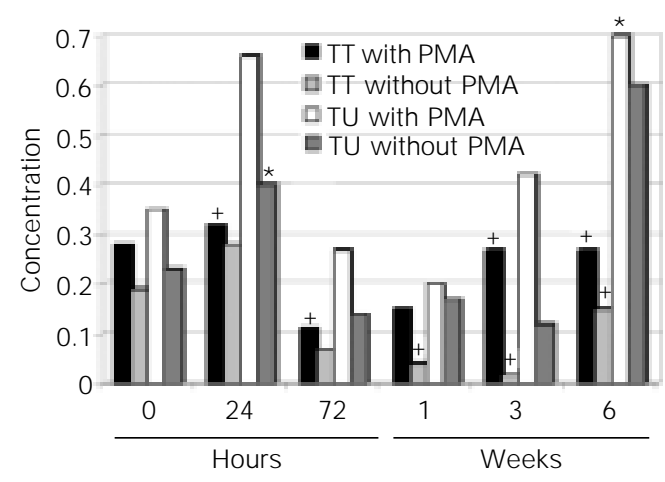

Figure 3. Functional status of macrophages present in the bronchoalveolar lavage of thalidomide-treated (TT) and untreated (TU) Swiss mice. The assay was based on spontaneous (without PMA) and induced (with PMA) $\mathrm{H}_{2} \mathrm{O}_{2}$ release. Data are reported as medians. ${ }^{+} \mathrm{P}<0.05$ compared to the infected untreated group (Kruskal-Wallis test). $* \mathrm{P}<0.05$ compared to the untreated infected group (Kruskal-Wallis test). $\mathrm{PMA}=$ phorbol myristate acetate. 
Since macrophage spreading requires the activation of $\mathrm{PKC}$, a generic denomination for a family of serine/threonine kinases involved in numerous cellular processes (30), and since a direct interaction between thalidomide and several PKC isoforms (31) has been described, we suggest that the inhibitory activity of thalidomide on macrophage spreading is mediated by the PKC pathway.

Since spreading is an important mechanism of interaction between the phagocyte and the particle to be engulfed (32), any substance that inhibits macrophage spreading also interferes with the phagocytosis process. As phagocytosis stimulates the respiratory burst of cells in phagosomes by the NADPH oxidase pathway (32), the indirect effect of thalidomide on spreading, and consequently on phagocytosis, may also inhibit $\mathrm{H}_{2} \mathrm{O}_{2}$ release. Since oxygen radical metabolites elicit macrophage spreading (33), the inhibitory effect of thalidomide on macrophage spreading detected in the present study may be exacerbated by the inhibitory action of this drug on $\mathrm{H}_{2} \mathrm{O}_{2}$ production. Our results, similarly to what was described by others (32), suggest a link between the macrophage spreading process and $\mathrm{H}_{2} \mathrm{O}_{2}$ release during the course of infection.

Regardless of the extent to which phagocytic cells release $\mathrm{H}_{2} \mathrm{O}_{2}$, bacilli were observed in the pulmonary tract until the end of the experimental period, which suggests that other events must be involved in the clearance of $M$. avium by alveolar macrophages. Our results agree with those reported by Appelberg and Sarmento (34) who, studying mouse strains resistant and susceptible to infection with $M$. avium, observed that $\mathrm{H}_{2} \mathrm{O}_{2}$ production was frequently higher in the susceptible strain. Similarly, these data support those reported by Saunders and Cheers (3), who demonstrated that $M$. avium is a bacterium resistant to reactive oxygen species such as $\mathrm{H}_{2} \mathrm{O}_{2}$.

Mycobacteria are able to evade the antimicrobial activities of macrophages by sev- eral mechanisms; some investigators have suggested that activation of antibacterial killing by cytokines, particularly TNF- $\alpha$, is essential for the control of mycobacterial infections (7). According to Kindler et al. (35), the administration of TNF- $\alpha$-blocking substances to mice infected with BCG or $M$. tuberculosis results in increased mycobacterial load. Similarly, Flynn et al. (36) showed that mice unable to respond to TNF- $\alpha$ due to depletion of its receptor undergo $M$. tuberculosis infection much faster than control mice.

Considering the inhibitory activity of thalidomide against TNF- $\alpha$, an increased bacillary load was expected in infected mice with the administration of this drug. This, however, was not observed. With a few exceptions, thalidomide treatment did not affect the amount of viable bacilli in the pulmonary tract. A similar result was obtained by Moreira et al. (37) who evaluated this parameter in $M$. tuberculosis-infected mice. According to the cited authors, treatment with thalidomide had no impact on the host's ability to restrain the growth of bacilli. Thalidomide-treated and untreated animals showed the same amount of $M$. tuberculosis colonies 28 days post-infection.

The results obtained in the present study also indicate the biphasic behavior of bacilli in the pulmonary tract, with their presence occurring in the first hours and in the final weeks of the experimental period. This quiescent period suggests that bacilli, after the initial phase, find an adequate environment for multiplication in the pulmonary tract, resuming reproduction when the environment is appropriate. This is not a unique finding, but has also been observed in human leprosy, with some patients, denominated clear or inactive, maintaining persistent bacilli for many years (38).

Taken together, our results demonstrate the interference of thalidomide with the functional status of alveolar macrophages evaluated by cell spreading and $\mathrm{H}_{2} \mathrm{O}_{2}$ production, 
but with no effect on bacillary clearance. In view of these data and the effect of the drug on TNF- $\alpha$, our results suggest that the cytokine does not have a major role in mycobacterial death induced by alveolar macrophages. Although the inflammatory effects of $M$. avium can prevent mycobacterial multiplication for some time, they are not sufficient to achieve bacillary clearance. Indeed, under the conditions used, the pulmonary environment favored bacillary growth.

\section{References}

1. Greenwell-Wild T, Vásquez $N$, Sim $D$, Schito $M$, Chatterjee $D$, Orenstein J M \& Wahl SM (2002). Mycobacterium avium infection and modulation of human macrophage gene expression. J ournal of Immunology, 169: 6286-6297.

2. Gilbertson B, Zhong J \& Cheers C (1999). Anergy, IFN- $\gamma$ production, and apoptosis in terminal infection of mice with Mycobacterium avium. J ournal of Immunology, 163: 2073-2080.

3. Saunders BM \& Cheers C (1996). Increased lung cell cytotoxic but not bactericidal or phagocytic activity in Mycobacterium avium complex-infected mice. Cellular Immunology, 171: 48-54.

4. Schlesinger LS, Bellinger-Kawahara CG, Payne NR \& Horwitz MA (1990). Phagocytosis of Mycobacterium tuberculosis is mediated by human monocyte complement receptors and components C3'. J oumal of Immunology, 144: 2771-2780.

5. Fiori PL, Rappelli P, Casu G, Delugo G, Turín F \& Cappuccinelli PA (2000). Pre-existing infection by Mycobacterium avium subsp. avium modulates anti-Cryptococcus neoformans and anti-Candida albicans activities in human macrophages. Microbial Pathogenesis, 29: 93100.

6. Britton WJ , Roche PW \& Winter N (1994). Mechanisms of persistence of mycobacteria. Trends in Microbiology, 2: 284-289.

7. Britton WJ , Meadows N, Rathjen DA, Roach DR \& Briscoe H (1998). Tumor necrosis factor mimetic peptide activates a murine macrophage cell line to inhibit mycobacterial growth in a nitric oxidedependent fashion. Infection and Immunity, 66: 2122-2127.

8. Engele $M$, Stoßel $E$, Castiglione $K$, Schwerdtner $N$, Wagner $M$, Bolcskei P, Rollinghff M \& Stenger S (2002). Induction of TNF in human alveolar macrophages as a potential evasion mechanism of virulent Mycobacterium tuberculosis. J oumal of Immunology, 169: 1328-1337.

9. Furney SK, Skinner PS, Roberts AD, Appelberg R \& Orme IM (1992). Capacity of Mycobacterium avium isolates to grow well or poorly in murine macrophages in their ability to induce secretion of tumor necrosis factor. Infection and Immunity, 60: 4410-4413.

10. Tracey KJ \& Cerami A (1994). Tumor necrosis factor: a pleiotropic cytokine and therapeutic target. Annual Review of Medicine, 45: 491-503.

11. Denis M (1991). Growth of Mycobacterium avium in human monocytes: identification of cytokines which reduce and enhance intracellular microbial growth. Clinical and Experimental Immunology, 21: 391-395.

12. Bermudez LE \& Young LS (1988). Tumor necrosis factor, alone or in combination with IL-2, but not INF-gamma, is associated with macrophage killing of Mycobacterium avium complex. J ournal of Immunology, 140: 3006-3013.

13. Bermudez LE, Stevens P, Kolonoski P, Wu M \& Young LS (1989). Treatment of disseminated Mycobacterium avium complex infection in mice with recombinant interleukin-2 and tumor necrosis factor. J ournal of Immunology, 143: 2996-3000.

14. Appelberg R, Castro AG, Pedrosa J , Silva RA, Orme IM \& Minoprio $P$ (1994). Role of gamma interferon and tumor necrosis factor alpha during T-cell-independent phases of Mycobacterium avium infection. Infection and Immunity, 62: 3962-3971.

15. Gangadharam PRJ \& Pratt PF (1989). Susceptibility of beige mice to Mycobacterium avium complex infections by different routes of challenge. American Review of Respiratory Disease, 139: 10981104.

16. Marriot JB, Muller G \& Dalgleish AG (1999). Thalidomide as an emerging immunotherapeutic agent. Immunology Today, 12: 538540.

17. Sinhorini IL, Merussi J L \& Mariano M (1994). Role of lymphatic drainage on the development of Calmette-Guérin Bacillus-induced granulomas in the hamster. International Archives of Allergy and Immunology, 103: 166-174.

18. Ridley DS \& Hilson GRF (1967). A logarithmic index of bacilli in biopsies. I. Method. International J ournal of Leprosy, 35: 184-186.

19. Rabinovitch M, Menejias RE \& Russo M (1977). Increased spreading of macrophage from mice treated with interferon inducers. Cellular Immunology, 29: 86-95.

20. Russo M, Teixeira HC, Marcondes MCG \& Barbuto J AM (1989). Superoxide hydrogen peroxide release by activated macrophages. Brazilian J ournal of Medical and Biological Research, 22: 12711273.

21. Faraco J (1938). Bacilos de Hansen e cortes de parafina: método complementar para pesquisa de bacilos de Hansen em cortes de material incluído em parafina. Revista Brasileira de Leprologia, 6: 177-180.

22. Fite GL (1938). Staining of acid-fast bacilli in paraffin sections. American J ournal of Pathology, 14: 491-507.

23. Norman GR \& Streiner DL (1994). Biostatistics - The Base Essentials. Mosby Year Book, St. Louis, MO, USA.

24. Ferreira CSA (1993). Características imunopatológicas da paracoccidioidomicose experimental murina induzida por via intravenosa. Master's thesis, Instituto de Ciências Biológicas, Universidade de São Paulo, São Paulo, SP, Brazil.

25. Vilani-Moreno $F$, Fecchio $D$, Mattos $\mathrm{MCl}$, Moscardi-Bacchi $M$, Defaveri J \& Franco M (1998). Study of pulmonary experimental paracoccidioidomycosis by analysis of bronchoalveolar lavage cells: resistant vs susceptible mice. Mycopathologia, 141: 79-91.

26. Roach DR, Bean AG, Demangel C, France MP, Briscoe $H$ \& Britton WJ (2002). TNF regulates chemokine induction essential for cell recruitment, granuloma formation, and clearance of mycobacterial infection. J ournal of Immunology, 168: 4620-4627.

27. Cameiro-Filho BA, Souza ML, Lima AA \& Ribeiro RA (2001). The effect of tumor necrosis factor (TNF) inhibitors in Clostridium difficile toxin-induced paw oedema and neutrophil migration. Pharmacology 
and Toxicology, 88: 313-318.

28. Lokensgard J R, Hu S, van Fenema EM, Sheng WS \& Peterson PK (2000). Effect of thalidomide on chemokine production by human microglia. J ournal of Infectious Diseases, 182: 983-987.

29. Bilyk N, Mackenzie J S, Papadimitriou J M \& Holt PG (1988). Functional studies on macrophage populations in the airways and the lung wall of SPF mice in the steady-state and during respiratory virus infection. Immunology, 65: 417-425.

30. Yue L, Lu S, Garces J , J in T \& Li J (2000). Protein kinase C-regulated dynanamitin-enriched myristoylated alanine-rice $C$ kinase substrate interaction is involved in macrophage cell spreading. J ournal of Biological Chemistry, 275: 23948-23956.

31. Meierhofer C, Dunzendorfer S \& Wiedermann CJ (1999). Protein kinase C-dependent effects on leukocyte migration of thalidomide. J oumal of Infectious Diseases, 180: 216-219.

32. Sampaio SC, Sousa-e-Silva MCC, Borelli P, Cury R \& Cury Y (2001). Crotalus durissus terrificus snake venom regulates macrophage metabolism and function. J ournal of Leukocyte Biology, 70: 551557.

33. Ogura M \& Kitamura M (1998). Oxidant stress incites spreading of macrophages via extracellular signal-regulated kinases and p38 mitogen-activated protein kinase. J ournal of Immunology, 161: 35693574.

34. Appelberg R \& Sarmento AM (1990). The role of macrophage activation and of BCGencoded macrophage function(s) in control of Mycobacterium avium infection in mice. Clinical and Experimental Immunology, 80: 324-331.

35. Kindler V, Sappino AP, Grau GE, Piguet GF \& Vassali P (1989). The inducing role of tumor necrosis factor in the development of bactericidal granulomas during BCG infection. Cell, 56: 731-740.

36. Flynn J L, Goldstein MN, Chan J , Triebold KJ , Pfeffer K, Lowenstein CJ , Schreiber R, Mark TW \& Bloom BR (1995). Tumor necrosis factor- $\alpha$ is required in the protective immune response against Mycobacterium tuberculosis in mice. Immunity, 2: 561-572.

37. Moreira AL, Wang J, Sarno EM \& Kaplan G (1997). Thalidomide protects mice against LPS-induced shock. Brazilian J ournal of Medical and Biological Research, 30: 1199-1207.

38. Hastings RC (1994). Leprosy. 2nd edn. Churchill Livingstone, Edinburgh, UK. 